\title{
Use of a mucus thread for vertical movements in the tropical freshwater snail Mayabina pliculosa (Pulmonata: Physidae): a correction
}

\author{
Julián Monge-Nájera \\ Vicerrectoría de Investigación, Universidad Estatal a Distancia, 474-2050 San Pedro, Montes de Oca, San José, Costa Rica; julianmonge@gmail.com
}

Received 11-V-2010 Corrected 31-V-2010 Accepted 16-VI-2010

\section{ABSTRACT}

The tropical freshwater snail Mayabina pliculosa ("Aplexa fuliginea") uses a mucus thread for vertical movements in the water column, not buoyancy as previously reported.

KEY WORDS

Locomotion, buoyancy, pulmonate snails, correction, Costa Rica.

\section{RESUMEN}

El caracol dulceacuícola tropical Mayabina pliculosa ("Aplexa fuliginea") usa hilos de mucus para moverse verticalmente en la columna de agua, no flotación como se informó previamente.

PALABRAS CLAVE

Locomoción, flotación, caracol pulmonado, corrección, Costa Rica.
According to Taylor (2003, page 97), the species studied by Monge-Nájera (1984) is not "Aplexa fuliginea" but Mayabina pliculosa (Martens, 1898). The biology of this tropical freshwater snail is, like that of other tropical snails, poorly known. It occurs in ponds and slow streams, where it feeds on bottom vegetation and carrion; its natural history was described late in the previous century (MongeNájera 1984).

In my previous article about the species in Costa Rica (Monge-Nájera 1984) I described that the animal "adjusts its buoyancy to move vertically in the water column". However, after that publication I noticed that in fact it moves along a barely visible mucus thread anchored from surface to bottom. Thus, my original interpretation that this slow vertical movement was produced by changes in buoyancy (Monge-Nájera 1984) must be discarded.

To reach food near the land, the snails descend by the pond walls, but when the food is farther away, they glide in the water surface (Monge-Nájera 1984) until they are above the food and then make a vertical descent by a mucus thread. Periodically they move up the thread to breath. This type of locomotion is known in other species (Baker 1911, Dawson 1911, Deliagina \& Orlovsky 1990).

The evolutionary origin of this behavior, that requires a longer route than following the ground, may be related to a lower consumption of energy and is possible because they live in slow waters.

I thank Robert T. Dillon, Jr. (College of Charleston, South Carolina) for kindly advising me on early literature about snail locomotion.

\section{REFERENCES}

Baker, F. C. 1911. The Lymnaeidae of North and Middle America, Recent and Fossil. Special Publication 3, Chicago Academy of Sciences, p. 33.

Dawson, J. 1911. The Biology of Physa. Cold Spring Harbor Behavior Monographs 1: 1 - 120.

Deliagina, T.G. \& G. N. Orlovsky. 1990. Control of locomotion in the freshwater snail Planorbis corneus. I. Locomotory repertoire of the snail. Journal of Experimental Biology 152: 389-404.

Monge-Nájera, J. 1984. Preliminary observations on the ecology and behavior of Aplexa fuliginea (Pulmonata: Physidae). Brenesia 22: 69-83.

Taylor D. W. 2003. Introduction to Physidae (Gastropoda: Hygrophila). Biology, classification, morphology. Revista de Biología Tropical 51(Suppl. 1): 1-299. 